\title{
A Preliminary Study to Detect Urban Changes and Its Relationship to the Flash Floods Disaster in Jeddah City
}

\author{
Ranya Fadlalla Abdalla Elsheikh ${ }^{1,2}$ \\ ${ }^{1}$ Department of Geographic and GIS, Faculty of Arts \& Humanities, Women Branches, King Abdul Aziz University, Jeddah, \\ Kingdom of Saudi Arabia \\ ${ }^{2}$ Department of GIS, School of Survey, Faculty of Engineering, Sudan University of Science and Technology, Khartoum, Sudan \\ Email:rfalsheikh@kau.edu.sa
}

How to cite this paper: Elsheikh, R.F.A. (2017) A Preliminary Study to Detect Urban Changes and Its Relationship to the Flash Floods Disaster in Jeddah City. Journal of Geographic Information System, 9, $1-7$.

https://doi.org/10.4236/jgis.2017.91001

Received: December 25, 2016 Accepted: February 13, 2017

Published: February 16, 2017

Copyright $\odot 2017$ by author and Scientific Research Publishing Inc. This work is licensed under the Creative Commons Attribution International License (CC BY 4.0).

http://creativecommons.org/licenses/by/4.0/

\begin{abstract}
Jeddah is one of the most attractive cities in Saudi Arabia. The expansion of urban area becomes essential due to rapid population and housing demand. Many environmental and economic problems could be occurring in absence of correct spatial planning. In 2009 and 2011, many of people were killed and suffered from the flash flood disaster in Jeddah. The aim of this paper is to provide clear indicator for the change detection in the urban cover from the period of 1984 to 2014 in Jeddah. Also it indicates Cleary the relation between the urban expansion and flash flood hazards event. Change detection techniques was applied for Remote Sensing data and integrated into GIS environment. Change detection analysis shows that the urban areas increased from 170 to $390 \mathrm{~km}^{2}$. Urban expansion increased dramatically toward north and east. While it decreased towards south. Digital elevation model obtained from satellite image was used to extract watershed and stream networks. Drainages path way were blocked by residential area and contributed to flash flood occurrence. This study can be useful for future planning and for sustainable environment.
\end{abstract}

\section{Keywords}

Change Detection, GIS, Flash Flood, Urban, Remote Sensing

\section{Introduction}

Urban growth leads to change in landuse and land cover change especially in developing countries [1]. Jeddah is the main gateway to Makah. The economic growth and the huge number of visitors and population move the wheal of urbanization very fast toward the expansion and progress. Such rapid growth with 
limited planning can contribute to environmental problem [2] [3]. The disaster of Jeddah's flash flood occurred in November 2009 and January 2011. These two flood events killed 113 people in 2009 and infrastructure was destroyed [4]. Accurate change detection of urban surface is important for understanding relationships between human and environment phenomena to support decision making [5]. There are many applications of RS and GIS in different types of hydrological studies [6] [7] [8]. The relationship between the land use changes and the flash flood hazards through GIS-based analysis were approved [9].

Change detection in Urban growth involves the analyses of satellites images for the same geographic area at different period of times [10]. Geographic Information System (GIS) is a powerful tool for data management and analyses on other hand remote sensing can integrated with GIS to provide clear indicator for change detection.

Change detection in Urban growth involves the analyses of satellites images for the same geographic area at different period of times [11]. The aim of this paper to map the change detection areas in urban land cover for Jeddah city. Three LandSat satellite images (1984, 1992 and 2014) were analyzed to provide clear indicator for the urban growth. Digital elevation model was used to map the watershed and drainage networks. The relation between the urban expansion and flash flood hazards event were determined.

\section{Material and Method}

\subsection{Study Area and Data Sources}

Jeddah is the main gateway to Mecca and the second largest city in Saudi Arabia. The location of the city close to the Red Sea increases the number of visitors and contributed to economical development (see Figure 1).

Satellites data were collected from Earth Explorer (US/GS) in three different periods as described below (see Figure 2):

LandSat 5 TM 1984.

LandSat 7 ETM 2002.

LandSat 8 ETM 2014.

DEM (SRTM: Shutter Radar Topography Model).

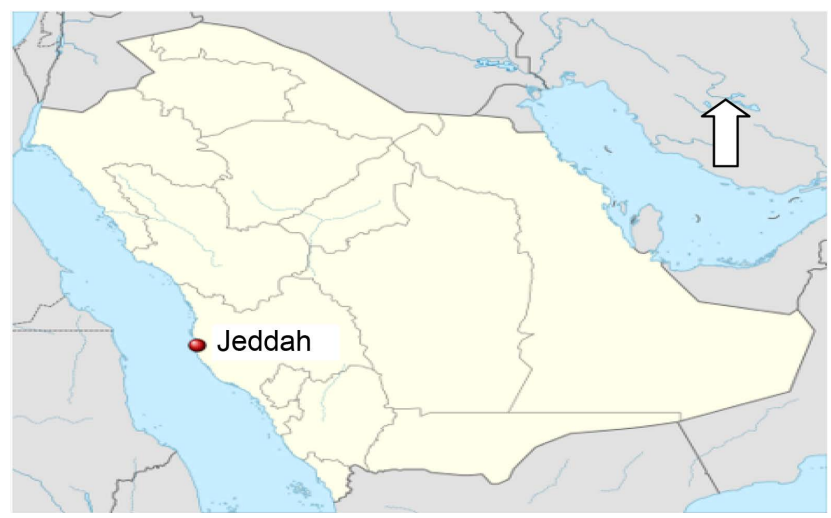

Figure 1. Location of the study area. 

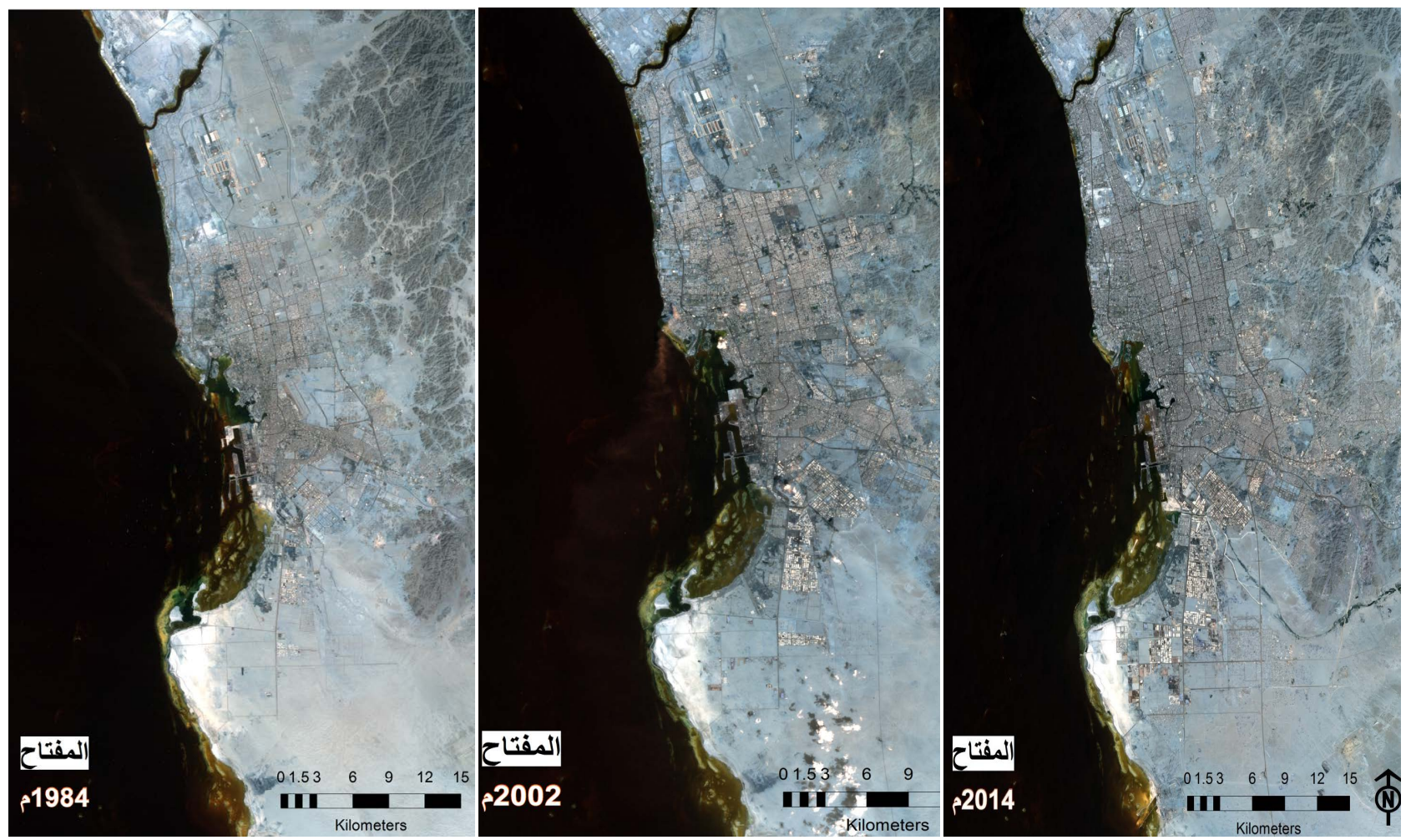

Figure 2. Satellites images at different period of time.

\subsection{Digital Image Processing}

In spectral change detection, images of different dates are transformed into a new single-band or multi-band image. The resultant image contains the spectral changes and it must be further processed to assign the changes to urban land cover [12]. Raster calculator in ArcMap and classification tool was used to process the image.

The process described by [13] was used to convert LandSat 5 TM DN data to LandSat 7 ETM DN data as in the equation below

$$
\text { DN7 }=\left(\text { Slope }_{\lambda} \times \text { DN5 }\right)+\text { int ercept }_{\lambda}
$$

where

DN7 is the Landsat 7 ETM+ equivalent DN data,

DN5 is the Landsat 5 TM DN data, and the slope and the intercept are bandspecific numbers given by the inverse of those found in [13]. Then DNs Values were converted to Radiance value by using Equation (2)

$$
\mathrm{L}_{\lambda}=\left(\text { gain }_{\lambda} \times \mathrm{DN} 7\right)+\text { bias }_{\lambda}
$$

where

$$
\mathrm{L}_{\lambda}=\text { calculated radiance }
$$

The latest gain and bias numbers for the Landsat 7 ETM+ sensor are given in [14]. After that the Radiance data were converted to Reflectance data $\left(\mathrm{R}_{\lambda}\right)$ and the latest were corrected. Finally the DN values of the LandSat 8 (2014) were converted to spectral radiance using the factors of radiance rescaling in metadata file.

$$
\mathrm{L}_{\lambda}=\text { MLQcal }+\mathrm{AL}
$$


where: $\mathrm{L}_{\lambda}=$ TOA spectral radiance $(\mathrm{w} / \mathrm{m}-2 / \mathrm{sr}-1 / \mu \mathrm{m}-1)$.

$\mathrm{ML}=$ Band-specific multiplicative rescaling factor from the metadata (RA-

DIANCE_MULT_BAND_x, where $\mathrm{x}$ is the band number).

$\mathrm{AL}=$ Band-specific additive rescaling factor from the metadata (RA-

DIANCE_ADD_BAND_x, where $\mathrm{x}$ is the band number).

Qcal $=$ Quantized and calibrated standard product pixel values (DN).

New Built-up Index (NBI equation) was used to extract urban areas automatically [15]. Watershed and drainage networks were extracted from DEM (SRTM: Shutter Radar Topography Model) by using Arc Map 10.2.

\subsection{Data Analysis}

In Jeddah, increasing of economy activities and growing population leads o dynamic trend in urbanization. However this trend of urbanization lead to change in landuse and land cover and it contributed to hazared occurance. The cause of flood in urban area is resulted of unplanned and uncontrolled city growth. The massive developments narrow the passes of wadi and decrease the the capacity of catchments area. Land use changes with combination of meteorological and hydrological events have significantly contributed to flood in urban area [16].

\section{Result and Discussion}

The built up index provide clear indicator for the urban area in the years 1984, 2002 and 2014 (see Figure 3).

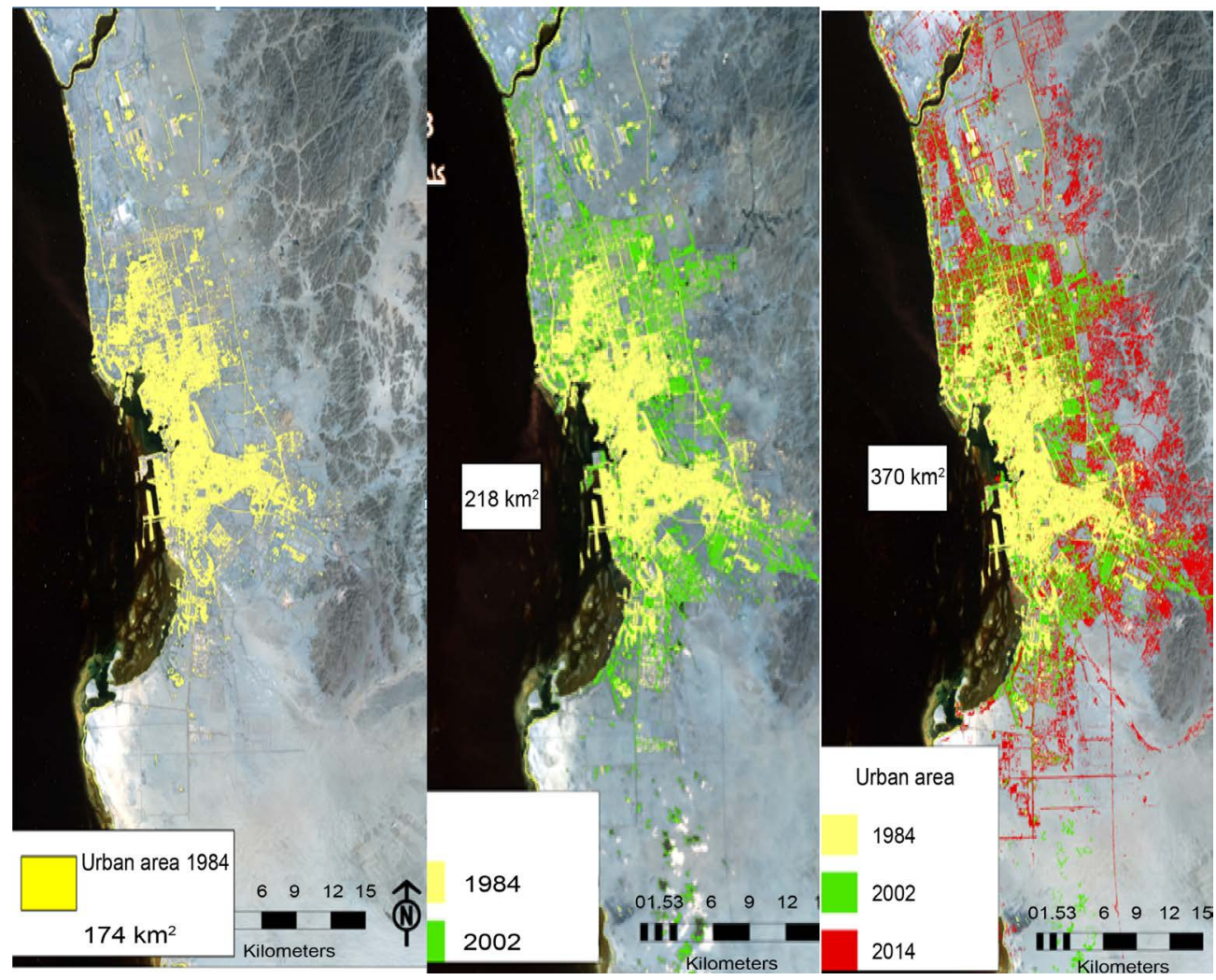

Figure 3. Urban expansion from 1984 to 2014. 
Change detection analysis shows that the urban areas increased from 170 to $390 \mathrm{~km}^{2}$. Urban expansion increased dramatically toward north and east. While it decreased towards south. The drainage networks and the watershed were extracted from DEM model by s = using hydrological tool in ArcGIS (see Figure 4).

The overlay process was implemented for the drainage network layer and the residential area. The overlay demonstrated that urban expansion is one of the factor that contributed the causes of flash flood event happened in Jeddah 2009 and 2011. The satellites image clearly shown that valley bath was blocked with residential area as indicated in Figure 5. The red color in Figure 5 indicates that most changeable area from 2002 to 2014. A few of residential zones for the study area lie in the lowest points of the drainage pathway (wadi) which were strongly affected. The finding of this is study in the agreement with latest literature in the same field [4].

\section{Conclusion}

The current study compiled the remote sensing data with GIS technology to map urban changes with time. Different digital procedures were used for better detection. The DEM was used to extract the drainage network for the study area. The overlay process was used to demonstrate that urban expansion is one of the

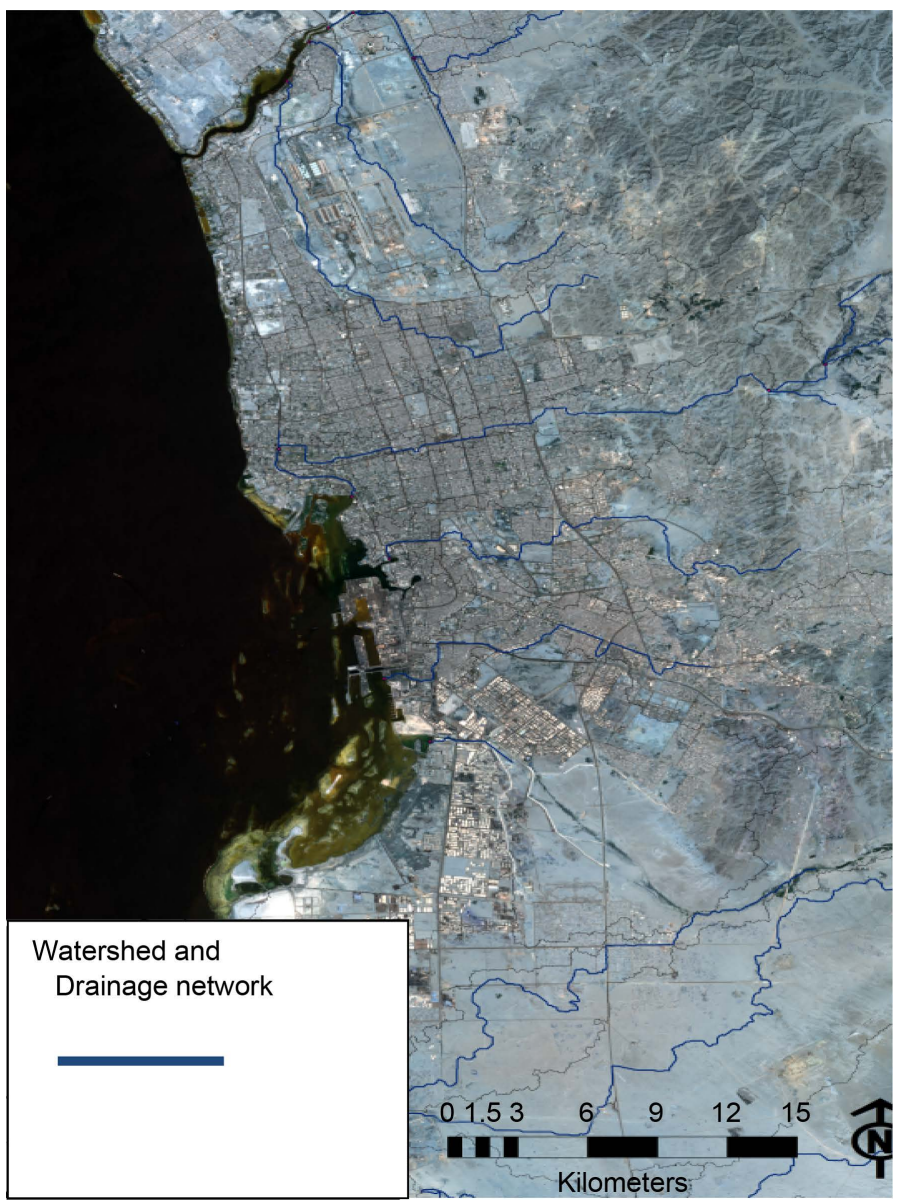

Figure 4. Watershed ad drainage network in the study area. 


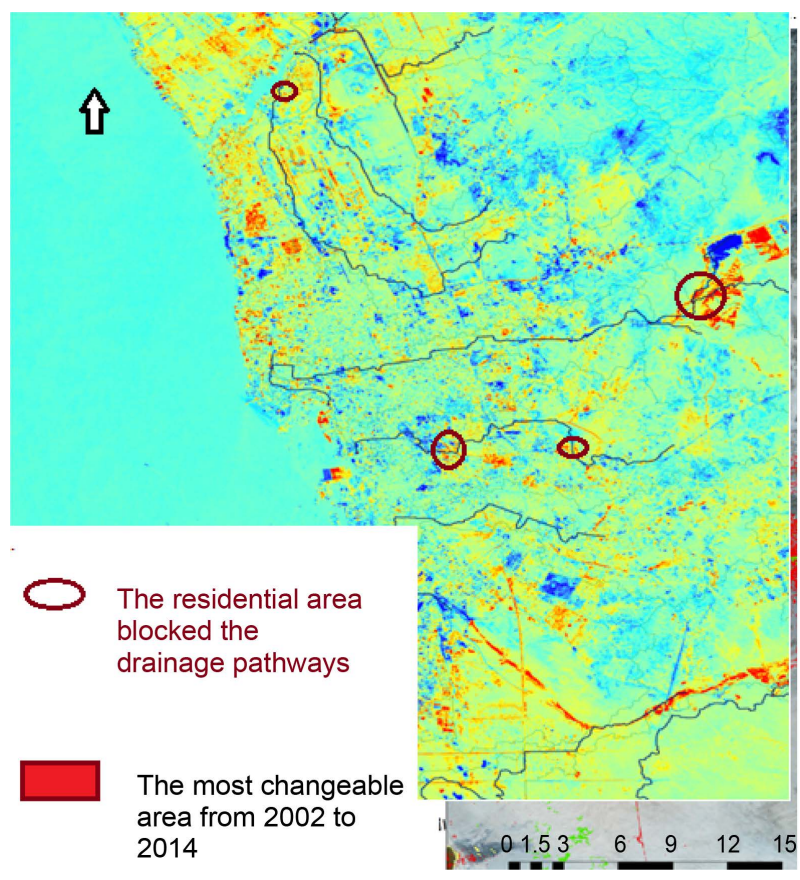

Figure 5. Residential zones for the study area lie in the drainage pathway (wadi) causing the flash flood.

causative factors of flash flood disaster. This study can be useful for better future planning.

\section{References}

[1] Hegazy, I.R. and Kaloop, M.R. (2015) Monitoring Urban Growth and Land Use Change Detection with GIS and Remote Sensing Techniques in Daqahlia Governorate Egypt. International Journal of Sustainable Built Environment, 4, 117-124. https://doi.org/10.1016/j.ijsbe.2015.02.005

[2] Tamilenthi, S. and Baskran, R. (2013) Urban Change Detection Based on Remote Sensing and GIS of Study of Salem Revenue Division, Salem District, Tmil Nadu, India. European Association of Geographers, 4, 50-59.

[3] Sankhala, S. and Singh, B. (2014) Evaluation of Urban Sprawl and Land Use Land Cover Change Using Remote Sensing and GIS Techniques: A Case Study of Jaipur City, India. International Journal of Emerging Technology and Advanced Engineering, 4, 66-72

[4] Youssef, A.M., et al. (2016) Analysis on Causes of Flash Flood in Jeddah City (Kingdom of Saudi Arabia) of 2009 and 2011 using Multi-Sensor Remote Sensing Data and GIS. Geomatics, Natural Hazards and Risk, 7, 1018-1042. https://doi.org/10.1080/19475705.2015.1012750

[5] Lu, D., Mausel, P., Brondízio, E. and Moran, E. (2004) Change Detection Techniques. International Journal of Remote Sensing, 25, 2365-2401. https://doi.org/10.1080/0143116031000139863

[6] Youssef, A.M., Abdel Moneim, A.A. and Abu El-Maged, S.A. (2005) Flood Hazard Assessment and Its Associated Problems Using Geographic Information Systems, Sohag Governorate, Egypt. Proceedings of the 4th International Conference on the Geology of Africa, Assiut University, Assiut, 15-17 November 2005, 1-17.

[7] Bates, P.D. (2012) Integrating Remote Sensing Data with Flood Inundation Models: 
How Far Have We Got? Hydrological Process, 26, 2515-2521. https://doi.org/10.1002/hyp.9374

[8] Wanders, N., Karssenberg, D., de Roo, A., de Jong, S.M. and Bierkens, M.F.P. (2014) The Suitability of Remotely Sensed Soil Moisture for Improving Operational Flood Forecasting. Hydrology and Earth System Sciences, 18, 2343-2357. https://doi.org/10.5194/hess-18-2343-2014

[9] Chang, H., Franczyk, J. and Kim, C. (2009) What Is Responsible for Increasing Flood Risks? The Case of Gangwon Province, Korea. Natural Hazards, 48, 339-354. https://doi.org/10.1007/s11069-008-9266-y

[10] Radke, R.J., et al. (2005) Image Change Detection Algorithms: A Systematic Survey. IEEE Transactions on Image Processing, 14, 294-307. https://doi.org/10.1109/TIP.2004.838698

[11] Mennecke, B.E. (1997) Understanding the Role of Geographic Information Technologies in Business: Applications and Research Directions. Journal of Geographic Information and Decision Analysis, 1, 44-68.

[12] Yuan, D., Elvidge, C.D. and Lunetta, R.S. (1999) Survey of Multi-Spectral Methods for Land-Cover Change Analysis in Remote Sensing Change Detection: Environmental Monitoring Methods and Applications. In: Lunetta, R.S. and Elvidge, C.D., Eds., Taylor \& Francis, London, 21-39.

[13] Vogelmann, J.E., Howard, S.M., Yang, L., Larson, C.R., Wylie, B.K. and Van Driel, J.N. (2001) Completion of the 1990's National Land Cover Data Set for the Conterminous United States. Photogrammetric Engineering and Remote Sensing, 67, 650662

[14] Chander, G., Markham, B.L. and Helder, D.L. ( 2009) Summary of Current Radiometric Calibration Coefficients for Landsat MSS, TM, ETM+, and EO-1 ALI Sensors. Remote Sensing of Environment, 113, 893-903. https://doi.org/10.1016/j.rse.2009.01.007

[15] Rogers, A.S. and Kearney, M.S. (2004) Reducing Signature Variability in Un-Mixing Coastal Marsh Thematic Mapper Scenes Using Spectral Indices. International Journal of Remote Sensing, 25, 2317-2335. https://doi.org/10.1080/01431160310001618103

[16] Situngkir, F., Sagala, S., Yamin, D. and Widyasari, A. (2014) Spatial Relationship between Land Use Change and Flood Occurrences in Urban Area of Palembang. 
Submit or recommend next manuscript to SCIRP and we will provide best service for you:

Accepting pre-submission inquiries through Email, Facebook, LinkedIn, Twitter, etc. A wide selection of journals (inclusive of 9 subjects, more than 200 journals)

Providing 24-hour high-quality service

User-friendly online submission system

Fair and swift peer-review system

Efficient typesetting and proofreading procedure

Display of the result of downloads and visits, as well as the number of cited articles Maximum dissemination of your research work

Submit your manuscript at: http://papersubmission.scirp.org/

Or contact jgis@scirp.org 